\title{
RESOURCES TO IMPROVE THE EFFECTIVENESS OF PERIODONTAL TREATMENT IN PATIENTS WITH DIABETES MELLITUS
}

DOI: 10.36740/WLek202103225

\author{
Galyna F. Biloklytska, Svitlana Yu. Viala \\ SHUPYK NATIONAL HEALTHCARE UNIVERSITY OF UKRAINE, KYIV, UKRAINE
}

\begin{abstract}
The aim: Is to characterize the «Medico-sociological map» developed by us to identify systemic and local risk factors for periodontal disease in patients with type I and II diabetes mellitus as a resource to improve the treatment of generalized periodontitis.

Materials and methods: We have developed a Medic-sociological map to identify systemic and local risk factors for periodontal disease in patients with type I and type II diabetes mellitus. Methods of accumulation of primary dental and endocrinological information, review and analytical methods. Statistical methods for comparing empirical data and their generalization.

Results: Thanks to the «Medico-sociological map» developed by us, systemic and local risk factors for the development of periodontal tissue diseases in patients with type I and II diabetes mellitus have been identified. Factors for improving the well-being of patients in the treatment of periodontal diseases have been comprehensively studied. Patients with type 1 and type 2 diabetes mellitus have been shown to give up healthy habits (cigarette smoking) and lead a healthy lifestyle and reduce the health risks that can be caused by generalized periodontitis in combination with diabetes mellitus.

Conclusions: It has been demonstrated that resources to improve the effectiveness of periodontitis treatment in patients with diabetes mellitus include not only cooperation with endocrinologists, but also our «Medico-sociological map» to identify systemic and local risk factors for periodontal disease in patients with type I and II diabetes mellitus.
\end{abstract}

KEY WORDS: periodontitis; diabetes mellitus; «Medico-sociological map»

Wiad Lek. 2021;74(3 p.ll):702-707

\section{INTRODUCTION}

Periodontitis as a concomitant disease of people suffering from type I and II diabetes mellitus has become a much more serious problem in recent decades, the elimination of which requires large efforts not only dentists but also specialists in endocrinology. The current concept of diabetes mellitus care treats comorbidities as an integral part of such people's lives.

Adequate adaptation of dental patients in the process of gradual treatment of periodontitis on the background of diabetes mellitus is increasingly largely moving into the plane of competence of dentists [1]. In patients with periodontitis, the microcirculation in the small vessels of the periodontium deteriorates, i.e. - the transport of oxygen and nutrients is disrupted, it is difficult to excrete the final products of metabolism [2]. In this context, bad habits are considered as a factor that provokes and causes additional comorbidities of people with periodontitis, patients with type I and II diabetes mellitus [3; 4 ].

In the course of the study, 156 patients were examined, of which 118 agreed to record information on the positions provided by our «Medico-sociological map». Thus, 75.64\% of dental patients agreed to cooperate with the further use of information provided about themselves in order to increase the effectiveness of treatment and prevention of periodontal disease.

\section{THE AIM}

The aim is to characterize the «Medico-sociological map» developed by us to identify systemic and local risk factors for periodontal disease in patients with type I and II diabetes mellitus as a resource to improve the treatment of generalized periodontitis. To show that the cooperation of dentists with endocrinologists, who examine and treat dental patients with diabetes mellitus, gives a tangible positive dynamics of recovery and preservation of human health, even against the background of bad habits.

\section{MATERIALS AND METHODS}

According to the review of available electronic content, the structure and functionality of medical cards of a dental patient are studied, which are managed both in public medical institutions and in private dental clinics and specialized dental offices. In the process of performing this work, system-review, analytical methods, as well as methods of comparison, extrapolation and generalization are used.

The literature sources in which the conditions and the reasons promoting treatment and prevention of diseases of periodontal fabrics at patients with a type II diabetes mellitus are investigated are analyzed [5]; cause functional disorders of the stomatognathic system [6] and problems of general somatic pathology [7]; deepened by recession 
Table I. The results of monitoring the average weekly blood glucose levels in the treatment of generalized periodontitis in patients with type I and type Il diabetes mellitus.

\begin{tabular}{|c|c|c|c|c|c|}
\hline Weeks & Minimum & Maximum & Average & The standard deviation & Coefficient of variation \\
\hline $1^{\text {st }}$ & 5.800 & 12.300 & 7.918 & 1.884 & 0.238 \\
\hline $2^{\text {nd }}$ & 5.400 & 11.300 & 7.733 & 1.487 & 0.192 \\
\hline $3^{\text {rd }}$ & 5.200 & 10.100 & 7.185 & 1.220 & 0.170 \\
\hline $4^{\text {th }}$ & 5.000 & 10.100 & 7.045 & 1.267 & 0.180 \\
\hline \multicolumn{6}{|c|}{ Decryption of data (in percent) } \\
\hline \multirow{2}{*}{ Mmol/I } & & \multicolumn{4}{|c|}{ Weeks } \\
\hline & & $1^{\text {st }}$ & $2^{\text {nd }}$ & $3^{\text {rd }}$ & $4^{\text {th }}$ \\
\hline$<6.0$ & & 12.12 & 12.12 & 24.24 & 21.22 \\
\hline $6.0-6.5$ & & 15.15 & 12.12 & 3.03 & 15.15 \\
\hline $6.6-7.0$ & & 12.12 & 3.03 & 21.22 & 18.18 \\
\hline $7.1-7.5$ & & 12.12 & 24.25 & 24.24 & 12.12 \\
\hline $7.6-8.0$ & & 21.22 & 18.18 & 6.06 & 12.12 \\
\hline $8.1-8.5$ & & 6.06 & 6.06 & 9.09 & 9.09 \\
\hline $8.6-9.0$ & & - & 9.09 & 3.03 & 3.03 \\
\hline $9.1-9.5$ & & - & - & 3.03 & 3.03 \\
\hline $9.6-10.0$ & & 6.06 & 3.03 & 3.03 & 3.03 \\
\hline $10.1-10.5$ & & - & 6.06 & 3.03 & 3.03 \\
\hline $10.6-11.0$ & & - & 3.03 & - & - \\
\hline $11.1-11.5$ & & 6.06 & 3.03 & - & - \\
\hline $11.6-12.0$ & & 6.06 & - & - & - \\
\hline $12.1-12.5$ & & 3.03 & - & - & - \\
\hline
\end{tabular}

of the gums [8], etc. Researchers note: in the complex treatment of severe periodontal disease in patients with type II diabetes mellitus, it is advisable to use pectin in the form of an oral agent, a hygienic prophylactic agent and a drug that forms a dosage form with prolonged exposure in the oral cavity; treatment of periodontal tissue diseases in severe manifestations can correct the level of capillary plasma glucose and blood pressure in patients with type II diabetes mellitus; the immediate results of treatment of periodontal tissue diseases depend on complex treatment, significantly reducing the aggressiveness of both periodontitis and diabetes mellitus [5, p. 108].

Based on the materials and applied research methods, an algorithm for creating a «Medico-sociological map» as an innovative tool for improving the effectiveness of dental care for patients with type I and II diabetes mellitus was developed. This map is also designed to capture psychological characteristics [9] and provides control over the timeliness of screening [10] as an important stage in the examination and treatment of dental patients with type I and II diabetes mellitus.

\section{RESULTS}

We consider the establishment, development and preservation of subject-subjectivity in communication with patients to be important in our dental practice. An open and interested dialogue «dentist - patient» increases the flow of informative interactions. As a result, quality contact is established and the patient's trust in the dentist's personality, in his professional preventive advice, in the process of treatment of periodontal diseases is increased. Patients with type I and II diabetes mellitus react sharply to such professional activity and communicative behavior of a dentist. These patients need not only professional treatment of periodontal diseases, but also special attention and complicity. The belief that a modern dentist should be just that, prompted us to develop a special «Medico-sociological map» to identify systemic and local risk factors for periodontal disease in patients with type I and II diabetes mellitus, which would also be a resource to improve treatment generalized periodontitis.

To this end, many questions have been implemented in the «Medico-sociological map», the answers to which give a much broader picture of patients. Here are the empirical data for only some positions.

Importance for patients of generalized periodontitis treatment in a dental clinic (only $27.12 \%$ of respondents go to the dentist; $30.51 \%$ do not pay attention to this problem; others are treated with folk remedies).

The attitude of patients to the presence of surrounding symptoms of generalized periodontitis (bleeding gums, bad 

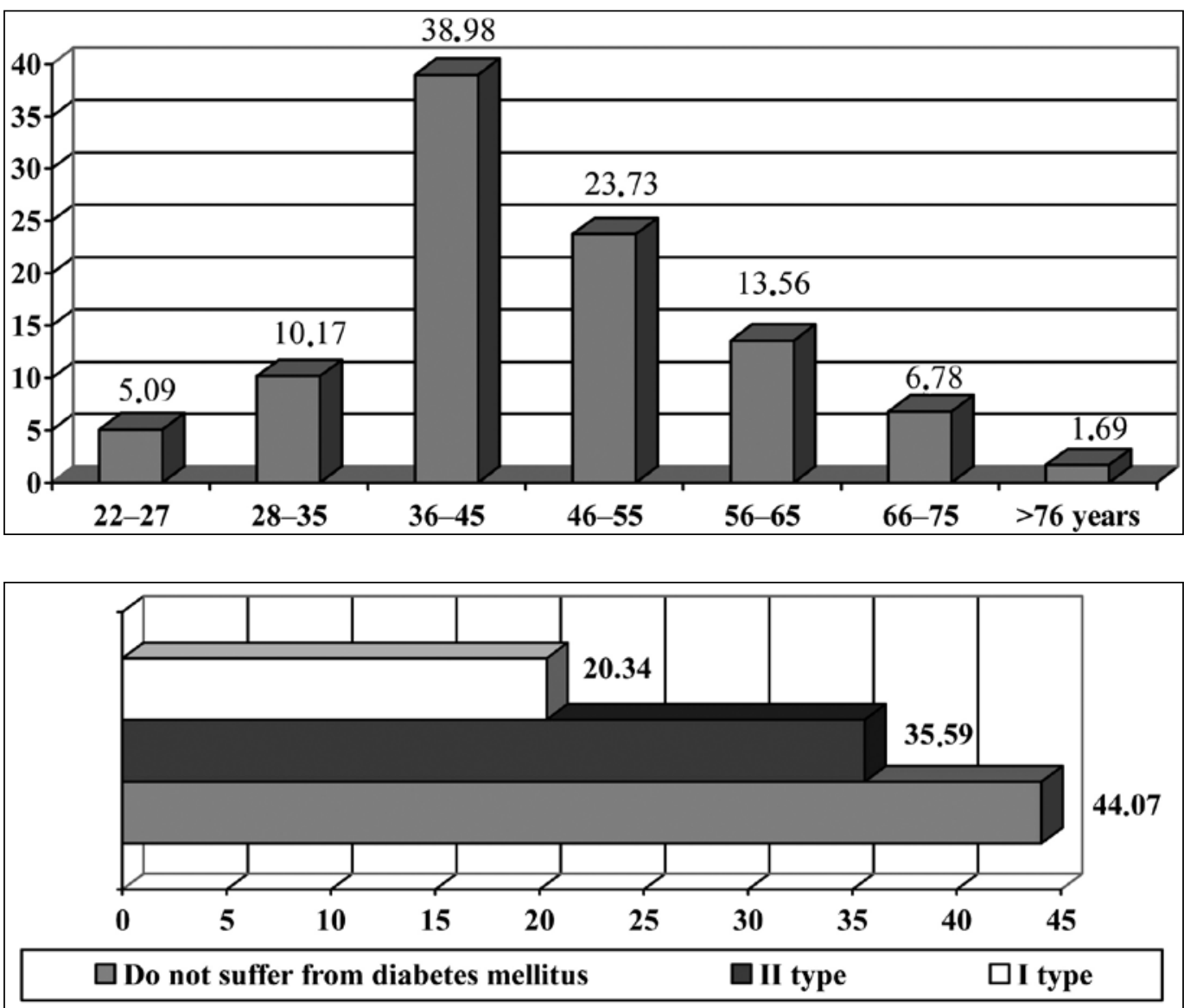

Fig. 1. Distribution of dental patients by age groups.

Fig. 2. Distribution of dental patients who are ill and do not have diabetes mellitus. breath, facial appearance, etc.) (20.34\% of respondents said they were indifferent to such symptoms).

Patients' trust in dentists $5.00 \%$ indicated a very high level of trust; $37.29 \%$ - high; $44.07 \%$ - average; $13.56 \%$ below average; no one said they did not trust dentists) .

The degree of adherence by patients to the advice of dentists on the prevention and treatment of generalized periodontitis (5.08\% indicated a very high degree of confidence; $49.15 \%$ - high; $35.59 \%$ - average; $8.47 \%$ - below average; $1.69 \%$ - very low).

Patients' awareness of the dependence of tooth loss on stress $(62.71 \%$ admitted that stress negatively affects the dental picture; $33.90 \%$ admitted that they never thought about it; $3.39 \%$ did not answer).

Awareness of patients with diabetes mellitus type I and II dependence of tooth loss on diabetes mellitus (91.67\% of respondents diagnosed with type 1 diabetes mellitus are aware of this dependence; among surveyed patients diagnosed with type 2 diabetes mellitus are aware of this dependence $76.19 \%$ ).

Awareness of patients with diabetes mellitus type I and II complications of periodontitis from the presence of diabetes mellitus (100.00\% of respondents diagnosed with «type I diabetes mellitus» are aware of this dependence; among surveyed patients diagnosed with «type II diabetes mellitus» are aware of this dependence $95.24 \%$ ).

The «Medico-sociological map» allows us to monitor the average weekly blood glucose levels in the treatment of generalized periodontitis in patients with type I and type II diabetes mellitus (Table I). The recorded data are subject to careful analysis in order to determine the optimal algorithm for the treatment of generalized periodontitis in patients with type I and type II diabetes mellitus and, if necessary, providing operative consultations by an endocrinologist.

The study also found that most dental problems were in patients aged 36 to 45 years $(38.98 \%$ of the total number of those who sought dental care). For comparison, in Fig. 1 provides information on dental problems in patients of different ages.

It was found that male patients $(52.24 \%)$ suffer the most from dental problems, which is $5.08 \%$ more than women $(47.46 \%)$.

$44.07 \%$ of patients are not diagnosed with diabetes mellitus. A total of $55.93 \%$ (type I - 20.34\%; type II - 35.59\%) of all type of dental patients suffer from type I diabetes mellitus (Fig. 2).

Systematic work with the "Medico-sociological map» made it possible to concentrate empirical data on the duration of diabetic disease of those who sought dental care.

It was found (Table II) that most patients (36.36\%) have type I and II diabetes mellitus for $6-10$ years. $33.33 \%$ have been living with this diagnosis for 11-20 years. From 1 to 5 years, $27.28 \%$ suffer from diabetes mellitus. Less than one year $-3.03 \%$.

Most dental patients with diabetic status are aged 36 to 55 years, which is $54.54 \%$ of the total number of those who sought dental care. Thus, the most able-bodied category 
Table Il. Distribution of patients by duration of diabetic diseases.

\begin{tabular}{cc}
\hline Duration of illness & $\begin{array}{l}\text { In \% to those who suffer from } \\
\text { type I and II diabetes mellitus }\end{array}$ \\
\hline Less than a 1 year & 3.03 \\
\hline $1-5$ years & 27.28 \\
\hline $6-10$ years & 36.36 \\
\hline $11-20$ years & 33.33 \\
\hline
\end{tabular}

Table III. Distribution of data on cigarette smoking among patients with type I and II diabetes mellitus.

\begin{tabular}{ccc}
\hline Alternatives & I type (\%) & II type (\%) \\
\hline Respondent smoking cigarettes & 41.67 & 19.04 \\
\hline $\begin{array}{c}\text { Respondent did not smoke and } \\
\text { does not smoke }\end{array}$ & 50.00 & 61.92 \\
\hline $\begin{array}{c}\text { Respondent quit smoking } \\
\text { cigarettes }\end{array}$ & 0.00 & 19.04 \\
\hline $\begin{array}{c}\text { Respondent Uses alternative } \\
\text { smoking }\end{array}$ & 8.33 & 0.00 \\
\hline
\end{tabular}

Table IV. Assessment of patients with diabetes mellitus, their well-being after comprehensive treatment of generalized periodontitis.

\begin{tabular}{ccc}
\hline Alternatives & I type (\%) & II type (\%) \\
\hline $\begin{array}{c}\text { The treatment effect is very } \\
\text { significant }\end{array}$ & 8.33 & 14.29 \\
\hline $\begin{array}{c}\text { The effect of treatment is above } \\
\text { average }\end{array}$ & 75.00 & 76.19 \\
\hline Treatment effect is negligible & 16.67 & 9.52 \\
\hline
\end{tabular}

of citizens has problems with diabetes mellitus and needs dental treatment and prevention of relevant diseases.

Male patients suffer the most from dental problems (52.24\% of all those who sought dental care). Based on empirical data, we state: among patients with type I and II diabetes mellitus, men $-51.52 \%$, and women $-48.48 \%$. It is safe to say that diabetes mellitus is more common in men. These data are representative only for our groups.
Bad habits (tobacco smoking) of dental patients with type I and II diabetes mellitus: $27.27 \%$ of dental patients with type I and type II diabetes mellitus have bad habits (smoke cigarettes); $57.58 \%$ have never smoked and do not smoke; $12.12 \%$ quit smoking and $3.03 \%$ use alternative smoking.

The distribution of data on cigarette smoking among patients with type I and type II diabetes mellitus is presented in Table III.

Data infographics (Table III) are presented in Fig. 3.

Among dental patients with type I and II diabetes mellitus, those who smoke cigarettes for 1-5 years, there are none; $6-10$ years $-22.22 \%$ (all - patients with type I diabetes mellitus); $11-20$ years $-33.33 \%$ (in this age category smokers with type I diabetes mellitus are twice as many as smokers with type II); $21-30$ years - $11.11 \%$ (all - patients with type I diabetes mellitus); $31-40$ years $-33.33 \%$ (all patients with type II diabetes mellitus); $66.67 \%$ of dental patients with type I and type II diabetes mellitus consume 16-20 cigarettes per day (ratio - 50x50); 22.22\% consume 6-10 cigarettes daily (all are patients with type I diabetes mellitus); $11.11 \%$ - 21-25 cigarettes per day (all - patients with type II diabetes mellitus).

In the Table IV presents data on the well-being of dental patients with diabetes mellitus (types I and II), after long-term comprehensive treatment of generalized periodontitis.

Comprehensive treatment of generalized periodontitis in combination with preventive measures and cooperation with endocrinologists who examine and treat dental patients with diabetes mellitus, gives, according to the patients themselves, tangible results. Statistically, this has the following expression:

- in the process of treating periodontal diseases $18.18 \%$ of patients quit smoking;

- $21.21 \%$ are at the stage of quitting smoking cigarettes and switch to alternative smoking;

- among those who reduce tobacco consumption, 9.09\% indicated that their well-being had greatly improved; feel an improvement of $45.45 \%$;

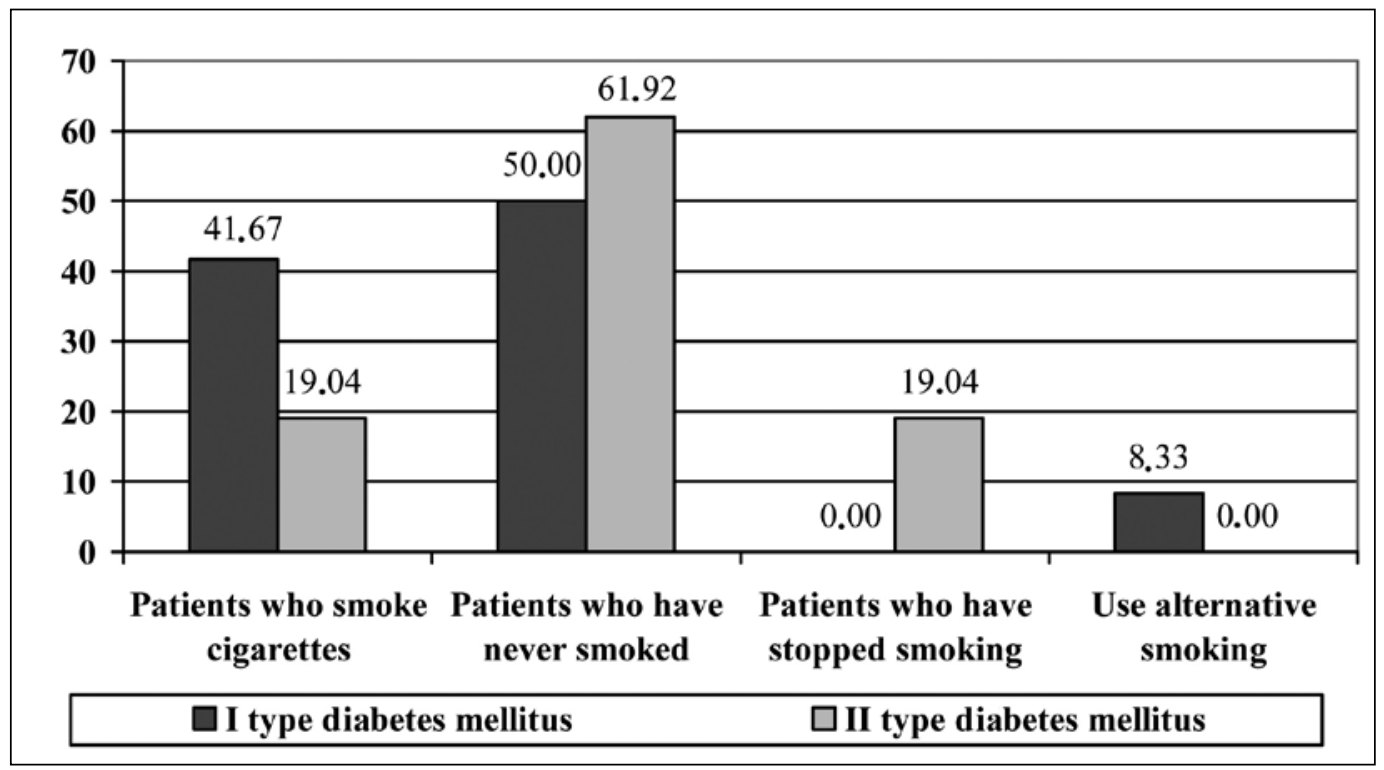

Fig. 3. Distribution of dental patients with type I and II diabetes mellitus, according to the presence of bad habits (cigarette smoking). 
- among those who do not smoke cigarettes, $15.15 \%$ after a comprehensive treatment of oral diseases rated their well-being at a high level, and $54.55 \%$ said that they felt better.

\section{DISCUSSION}

Dental diseases, as it turned out in recent decades, are very often provoked by diabetes. Researchers state that, «despite the fact that the possibilities of caries treatment and prevention grow every year, the indices of dental caries incidence and prevalence in Ukraine remain high. This was confirmed by the results of the oral health status study of type 2 diabetes mellitus patients aged 40 to 60 , whose caries prevalence was 100\%, and incidence by the DMFT Index was high» [4, p. 1030].

At the same time, according to experts from the European Federation of Periodontology, periodontal infection with a bilateral link between glycemia and periodontitis negatively affects blood glucose levels. Although the treatment can be based on all current research results and relevant recommendations, its effectiveness depends on the close cooperation of dentists and endocrinologists [11], as well as specialists in other related fields.

A variety of programs for the prevention and treatment of dental diseases are developed and implemented. Of course, dental care for a patient should be based, first of all, on a specific situational analysis - a result of the accumulation of relevant data when visiting dental care facilities. The World Health Organization (WHO) proposes to unify examination methods, analyze and compare different clinical outcomes, and recommends to use Combined Card for dental examination [12].

The Ministry of Health of Ukraine by order of February 14, 2012 № 110 approved the Medical Card of a dental patient (form № 043 / o) [13].

Medical card is an official legal document. Carefulness of its filling (the maximum amount of information about the condition of the dental patient) is of exceptional importance not only for determining the range of treatment, but also its procedure. A legal assessment of a dentist's behavior can also be made on the basis of this card.

For our many years of dental practice, we use not only regulations approved by the Ministry of Health of Ukraine, but also tools (map) of the Department of Therapeutic Dentistry of Institute of Dentistry of Shupyk National Medical Academy of Postgraduate Education.

Knowledge and application of basic and additional methods of examination of patients in therapeutic dentistry clinic, mastering the principles of filing medical history, skills of correct and professional (interdisciplinary) interviewing of patients are very important today. The ability to competently interpret empirical data is needed to establish an adequate diagnosis, develop and implement an optimal treatment plan for patients.

That is why in the course of our study there was an urgent need to develop such toolkit to identify systemic and local risk factors for periodontal disease in patients with type I and II diabetes mellitus.

\section{CONCLUSIONS}

It has been demonstrated that resources to improve the effectiveness of periodontitis treatment in patients with diabetes mellitus include not only cooperation with treating endocrinologists, but also our "Medico-sociological map» to identify systemic and local risk factors for periodontal disease in patients with type I and II diabetes mellitus.

It has been proven that the cooperation of dentists and treating endocrinologists who examine and treat dental patients with diabetes mellitus gives a tangible positive dynamics of restoring and maintaining human health, even against the background of bad habits.

The prospects of the study include the improvement of tools for the accumulation of primary dental and endocrinological information and its testing.

\section{REFERENCES}

1. Biloklytska G., Viala S. Psychological problems in patients with periodontitis against the background of diabetes. Eurasian scientific congress. The 3rd International scientific and practical conference - Eurasian scientific congress (March 22-24, 2020) Barca Academy Publishing, Barcelona, Spain. 2020:61-62.

2. Biloklytska G., Viala S., Koval A. Marketing research on dietary supplements for periodontitis in patient diabetes. Annals of Dental Specialty. 2020; 8(2): 67-78.

3. Gruzieva T.S., Galiienko L.I., Holovanova I.A. et al. Prevalence of bad habits among students of the institutions of higher medical education and ways of counteraction. Wiadomości Lekarskie. 2019; 72(3):384-390.

4. Barylo 0.S., Kanishyna T.M., Shkilniak L.I.The effects of diabetes mellitus on patients' oral health. Wiadomości Lekarskie. 2018;71(5): 1026-1031.

5. Kosenko S.V., Balaban I.0., Haioshko 0.B. et al.Vykorystannia pektynovyh rechovyn u hvoryh na tsukrovyi diabet 2 typu v kompleksnomu likuvanni zahvoriuvan tkanyn parodonta (povidomlennia 1) [Use of pectin in patients with diabetes mellitus type 2 in the complex treatment of the periodontal disease (report 2)]. Zaporozhye medical journal. 2014;3(84):105-108. (in Ukrainian).

6. Beloklitskaya G.F, Luzina 0.V. Shinirovaniye podvizhnykh zubob i vosstsnovleniye vklyuchennykh defektov zubnykh ryadov $v$ kompleksnom lechenii generalisovsnnogo parodontita [Splinting of mobile teeth and restoration of included dentition defects in the complex treatment of generalized periodontitis]. Sovremennaya stomatologiya. 2004;2:64-65. (in Russian).

7. Potapchuk A.M., Melnik V.S., Gorzov L.F., Rivis 0.Yu. Problemy zahalnosomatychnoi patolohii na stomatolohichnomu pryiomi [Problems of general-somatic pathology at dentistry reception]. Aktualni problemy suchasnoi medytsyny.2018;2(62):212-214. (in Ukrainian).

8. Beloklitskaya G.F, Kopchak 0.V. 0 mekhanizmakh razvitiya tservikal'noy gipertenzii i vozmozhnikh putyakh yee ustraneniya [ $0 n$ the mechanisms of development of cervical hyperesthesia and possible ways to eliminate it]. Sovremennaya stomatologiya. 2006;1: 65-69. (in Rassian).

9. Komnatskii B.Yu., Kulahina V.M. Psuholohichni osoblyvosti ta yakist zhyttia patsiientiv zi stomatolohichnymy hvorobamy iz suputnim tsukrovym diabetom, yaki potrebuiut mistsevoho zneboliuvannia pry terapevtychnyh i ortopedychnyh vtruchanniah [Psychological features and quality of life of patients with dental diseases with concomitant diabetes mellitus who require local anesthesia for therapeutic and orthopedic interventions]. Ukrainian stomatolohichnyi almanakh. 2013;3:24-27. (in Ukrainian). 
10. Antoshchuk R. Ya. Tsukrovyi diabet: etiolohiia zahvoriuvannia [Diabetes mellitus: etiology of the disease]. Molodyi vchenyi. 2016;6(33):277280. (in Ukrainian).

11. Maslak E.E., Naumova V.N. Interdisciplinary cooperation between dentists and endocrinologists for identification and management of diabetes mellitus. Diabetes mellitus. 2019;22(1):35-43. doi. org/10.14341/DM9581.

12. Kaskova L.F, Amosova L.I., Karpenko 0.0., et al. Profilaktyka stomatolohichnyh zahvoriuvan [Prevention of dental diseases]. Kharkiv: Fakt. 2011:392. (in Ukrainian).

13. Medychna karta stomatolohichnoho hvoroho. Forma pervynnoii oblikovoii dokumentatsii № 043/0 [Medical card of a dental patient. Form of primary accounting documentation № 043/0]. Kyiv. 2012. http://www.medconsulting.com.ua/f/formu/110/f043_o.doc. (in Ukrainian).

The article was prepared as part of the research work of the Department of Therapeutic Dentistry of Shupyk National Healthcare University of Ukraineon the topic: "Modern view on the diagnosis, prevention and prognosis of major dental diseases in young people» (state registration number 0117U002465; deadline 2017-2021).

\section{ORCID and contributionship:}

Galyna F. Biloklytska: 0000-0002-3039-0500 A, E, F

Svitlana Yu. Viala: 0000-0002-7190-0044 ${ }^{\text {B, C, D }}$

\section{Conflict of interest:}

The Authors declare no conflict of interest.

\section{CORRESPONDING AUTHOR}

Svitlana Yu. Viala

Shupyk National Healthcare University of Ukraine

9 Dorohozhytska St., 04112 Kyiv, Ukraine

tel: +380972759075

e-mail:svsv017@gmail.com

Received: 26.11 .2020

Accepted: 12.03 .2021

A - Work concept and design, B - Data collection and analysis, C - Responsibility for statistical analysis,

D-Writing the article, $\mathbf{E}$-Critical review, $\mathbf{F}$ - Final approval of the article 